\title{
Digitalization of garment in the context of circular economy DOI: 10.35530/IT.072.01.1824
}

\author{
ADINA VICTORIA ALBU \\ TUDOR CACIORA \\ ZHARAS BERDENOV \\ DORINA CAMELIA ILIES \\ BOGDAN STURZU
}

\author{
DANIELA SOPOTA \\ GRIGORE VASILE HERMAN \\ ALEXANDRU ILIES \\ GABRIELLA KECSE \\ CARMEN GEORGETA GHERGHELES
}

\section{ABSTRACT - REZUMAT \\ Digitalization of garment in the context of circular economy}

One of the principles of the circular economy is to recycle used or unused materials, in order to reuse them in the creation of new objects or the restoration of old ones. But due to the fragility, some of these materials, such as old textiles and clothing, are quite difficult to handle. This study presents a completely digital method with the help of which two pieces of clothing of different ages and physical properties, have been restored and stylized; the two pieces are made up of a traditional Romanian women's shirt about 100 years old and a modern sports $t$-shirt. For the application of the principles of the circular economy, the restoration-stylization processes of the pieces were based on the material and ornaments collected digitally from a series of old Romanian towels, which are currently no longer used. For this we considered the creation of 3D models of all the materials considered by the method of photogrammetry in Agisoft Metashape 1.6.2 Professional Edition and their processing in MeshLab 2020.2, as well as the vectorization of traditional motifs in ArcGis 10.6. Such an approach limits to the minimum the numbers of attempts that the restores have at their disposal while also allowing the obtaining, storage and transmission of information about traditional textiles, aimed at capturing the imagination of modern artists and designers to restore them for future generations.

Keywords: ethnographic textiles, photogrammetry, 3D modelling, digitalization, garment, digital design

\section{Digitalizarea articolelor de îmbrăcăminte în contextul economiei circulare}

Unul dintre principiile economiei circulare este acela de a recicla materialele uzate sau nefolosite, în vederea reutilizării lor, în crearea de obiecte noi sau restaurarea celor vechi. Dar datorită fragilității, unele dintre aceste materiale, precum materialele textile vechi, sunt destul de greu de manipulat. Acest studiu prezintă o metodă complet digitală, cu ajutorul căreia două piese vestimentare de diferite vârste și proprietăți fizice au fost restaurate și stilizate; cele două piese sunt alcătuite dintr-o cămașă tradițională românească pentru femei de aproximativ 100 de ani și un tricou sportiv modern. Pentru aplicarea principiilor economiei circulare, procesele de restaurare-stilizare a pieselor s-au bazat pe materialul și ornamentele culese în mod digital dintr-o serie de prosoape vechi românești, care în prezent nu mai sunt folosite. Pentru aceasta s-a avut în vedere crearea de modele $3 D$ pentru toate materialele luate în considerare prin metoda fotogrametriei în Agisoft Metashape 1.6.2 Professional Edition și prelucrarea acestora în MeshLab 2020.2, precum și vectorizarea motivelor tradiționale în ArcGis 10.6. O astfel de abordare limitează la minimum numărul de încercări pe care restauratorii le au la dispoziție, permițând totodată obținerea, stocarea și transmiterea informațiilor despre materialele textile tradiționale, menite să capteze imaginația artiștilor și designerilor moderni pentru a le reabilita pentru generațiile viitoare.

Cuvinte-cheie: textile etnografice, fotogrametrie, modelare 3D, digitalizare, articole de îmbrăcăminte, design digital

\section{INTRODUCTION}

The exacerbation of the environmental problems of the last period requires serious efforts from all the factors involved (social, economic, political, etc.) in identifying, testing and applying optimal solutions with effects in diminishing the anthropic impact on the environment. In this context, a special role is played by the concepts of sustainable development, sustainability and circular economy. The circular economy represents the frontier of environmental sustainability [1], a limit of the support capacity, which translates simply through the six $\mathrm{R}[2]$, reduces [3, 4], repair [5], reuse [6], recover [7], remanufacture $[7,8]$, recycle $[9,10]$.
In a circular economy, the products and materials contained are highly valued, as opposed to the traditional linear economic model, based on a "takemake-consumption-throw-away" model [11]. The transition to a circular economy could bring benefits such as: reduced pressures on the environment, increased security of supply of raw materials, increased competitiveness, innovation, etc., but also challenges: financial, consumer behaviour, etc. [12]. Therefore, sustainable development is a milestone, while sustainability is a driving force of the circular economy, with major implications for the economy, environment and society [13, 14]. 
In this context, considering that the textile industry is one of the largest industries with a negative impact on the environment, solutions are sought in order to reduce it. Applying the concept of circular economy to the textile industry is a challenge to which all stakeholders are called to make their contribution, starting with the academic environment and ending with the simple man, as the main beneficiary of the textile industry.

In essence, man is a creative being with an emphasized artistic-aesthetic spirit. Over time, he has tried to express his inner beliefs and experiences through art $[15,16]$. In this context, special attention was paid to the decoration of textile elements, especially clothing. Thus, they have been adorned with a series of plant motifs (leaves, flowers, plants, etc.), abstract (anthropomorphic, zoomorphic or cosmic), geometric (dots, straight lines, squares, triangles, etc.) with a very diverse chromatic specific to each community [17-20]. Clothing persons dressed in the former time played the most important "identification" function: it was possible to determine not only his gender and age, but also his social status, gender affiliation etc. Given the fact that textiles face a limited lifespan [21] and are most often accessible to a limited number of people, digitization seems to be the best solution for preserving, restoring, viewing and promoting these vestiges of the past [22]. The information obtained by digitizing the various textile elements and the embroidered motifs, can be stored together with other types of information (textual, graphic, photographic, audiovisual etc.) to be transmitted over generations or to be used today in the textile industry (traditional motifs, taken as sources of inspiration for designers in this field and beyond), audio-visual, constructions, etc. The digitization of ethnographic textiles is sometimes more special, due to the fragility and the difficulties of manipulation and it can be carried out using certain investigative techniques. The digitization of heritage objects includes the acquisition of spatial data, geometry modelling, digital archiving and posting in the online for the purpose of viewing by the general public, but also of studying, without interacting directly with the object [23]; thus, being able to easily follow the evolution of surface morphology as well as the evolution over time of some important processes for preservation, conservation etc., the details being very accurate [24].

As methods of digitization, photogrammetry and 3D modelling represent an important working tool that offers an overall, three-dimensional perspective [25], with implications in faithfully reproducing structural elements, as well as methods and techniques of obtaining and joining them.

Also, the 3D model offers a useful tool for designing and redesigning similar elements, with applicability in the preservation and informational rendering of cultural heritage [26-29], on the one hand, and in its use in the textile industry, on the other. The fashion industry is also increasingly attracted to the Virtual
Prototype (VP) of clothing products, which allows designers to make quickly changes to their design, saving time and costs, in an increasingly competitive world [30, 31].

Vectorization of traditional motifs and ornaments, as a technique of ethnographic digitization on textile products, is a very important operation, due to the fragility and the difficulties of manipulation, which implies certain specific working techniques [23, 24]. The results obtained after the vectorization can be used in the conservation, promotion and exploitation of the material cultural heritage.

Considering the ones listed above, the present study aimed at the digitally reutilization of some common elements compiling the Romanian textile heritage, it is about a series of old traditional peasant towels (60-70 years old) specific to Bihor County, Romania, decorated with traditional motifs. Thus, through processes of vectorization and 3D modelling based on photogrammetry technique, the material from which the traditional peasant towels are made and the traditional motifs with whom they are embellished represented the support for the reconstruction and stylization of two garments of different ages and uses; a traditional Romanian shirt and a sports t-shirt belonging to F.C. University of Oradea.

\section{MATERIALS AND METHODS}

The materials used to carry out the present study were made up of a number of four traditional Romanian peasant towels, an old traditional shirt and a t-shirt designed for sports activities.

For the digital reconstruction, a 3D model was created for each of the pieces considered. The models were created using a typical photogrammetric pipeline, based on creating 3D models by aligning and densely matching sets of 2D images [32, 33], using Agisoft Metashape 1.6.2 Professional Edition. The data was acquired with the help of a Canon EOS-1D Mark III camera, equipped with a $28.1 \times 18.7$ $\mathrm{mm}$ sensor and having a resolution of 10.7 megapixels. The photos thus obtained were sorted and preprocessed with the help of the Build-in option, in order to eliminate the inferior quality data which could affect the final texture; lining up for the creation of the models being only those photos considered optimal. To define the correct scale of each project, real manual measurements previously performed on the considered pieces were used, on the basis of which the correct calculation algorithms were then established for the two software so as to capture the actual dimensions of the objects.

The second digital operation aimed at vectorization $[16,34,35]$ of the traditional geometric motifs on the four traditional peasant towels in order to preserve the models and promote them by applying them on new materials. This was achieved by processing in ArcMap 10.6 of some very good quality 2D images focused on accurately presenting the details of the 
ornaments on the towels. This software was chosen due to the fact that it allows fast, very easy and accurate copying of the contours of the ornaments, due to the pointline-polygon type shape files it works with, these being also the main geometric shapes used in the traditional creation of these ornaments. At the same time, it allows different analysis, the change of colours and making patterns in case of repetitive motifs. The compatibility of this software with another from the ArcGIS package, namely ArcScene 10.6, allowed the export of models thus made
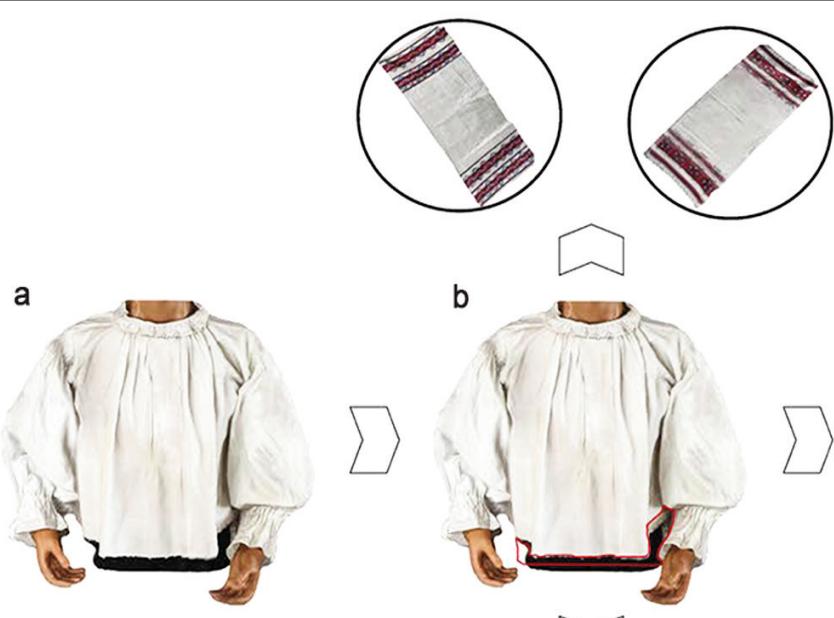

Q

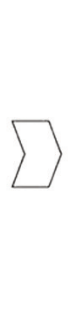

b
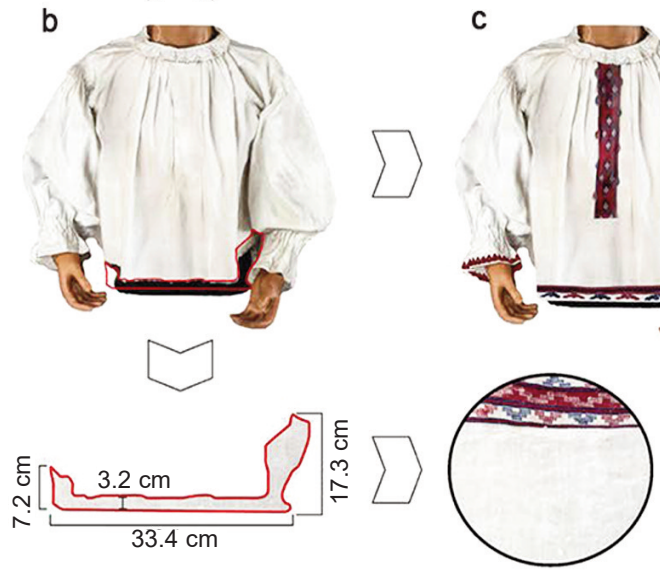

Fig. 1. The main stages in the process of restoration and stylization of traditional women's shirts "ie": $a$ - initial appearance of the traditional shirt; $b$ - model of restoration of the traditional women's shirts by digital reassembly of missing parts and stylization with traditional Romanian motifs present on other materials; $c$ - the final model in.wrl format, making

them visible for the three-dimensional reconstruction program MeshLab.

Finally, the 3D models and the traditional motifs created were important in MeshLab 2020.2, where the applicability of the techniques of rebuilding and styling the traditional shirt and the sports t-shirt brought on a real scale, based on the material taken from the traditional peasant towels, was tested in the context of the circular economy. Further on, the two $3 \mathrm{D}$ models depicting two clothing objects of different ages and uses, metric and volumetric operations were performed.

\section{RESULTS AND DISCUSSIONS}

Due to the large number of photographic data processed, their quality and the orientation of all photogrammetric processes to obtain a good texture, 3D models have free from noise, missing data or holes. For a proper presentation and to facilitate the analysis to be performed, the traditional shirt and the t-shirt were placed on a mannequin.

\section{Reconditioning-styling the traditional women's shirt "ie"}

With the help of modern digital techniques, the traditional female shirt without motives (figure 1,a) was processed in such a way that she was given a new look using pieces from traditional peasant towels. For this, a 3D image model was created for each of the targeted materials. Known as the fragility of textile materials and the fact that they are quite difficult to manipulate, such an approach was chosen because it limits the direct contact with the objects, allowing an unlimited number of analyses and attempts of restoration and/or stylization, without the initial appearance suffering.

The process of restoration and stylization of the traditional shirt (figure $1, b$ ) was channelled in two main directions. Due to the fact that at the bottom was missing a piece of fabric, the first operation involved the identification of a material that can be reused and which is also similar in terms of its nature, colour, pattern, age, etc. All these characteristics were identified in an old traditional towel. In the MeshLab 2020.2 program, the part of the missing fabric was measured digitally, creating a virtual model of the portion of material needed for the shirt re-assembly. This portion was cut from the traditional towel, after its 3D model was created in Agisoft Metashape 1.6.2 Professional Edition and then imported into MeshLab 2020.2. The piece of material thus generated was manually fixed in the correct position within the shirt model.

The stylization process consisted of reusing the traditional motifs cut from the traditional peasant towels and applying them on the shirt, so that the final model (figure $1, c$ ) resulted is an object built entirely on the basis of the principles of circular economy.

\section{Vectorization and reuse of traditional motifs}

The second case study focused on the vectorization of the models (figure 2) from the embroidery sewn on the old traditional peasant towels originating in Bihor County, Romania. This approach plays a decisive role in the creation of databases containing traditional Romanian ornaments, in order to preserve and promote them, while increasing their accessibility and 


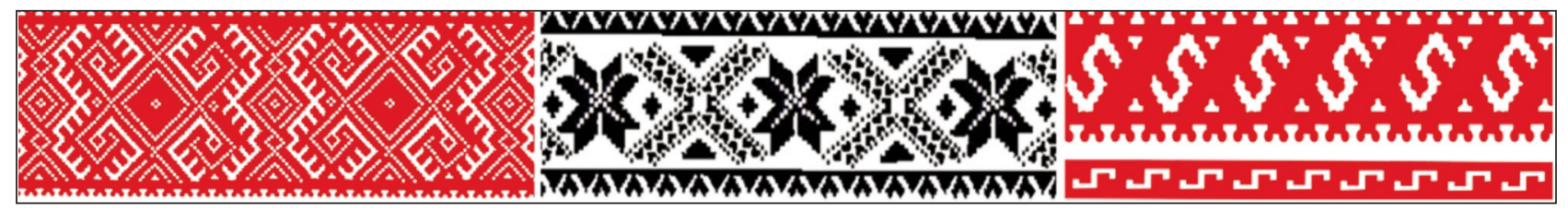

Fig. 2. Traditional motifs, specific for Bihor County (Romania), vectorized from traditional peasant towels

visibility among young people, artists and modern designers to integrate them into their creations, bringing them back, the fame from the past. The great advantage of these models is that they offer the possibility of performing operations such as changing the colour, size, restructure of the whole model or combining several models. At the same time,

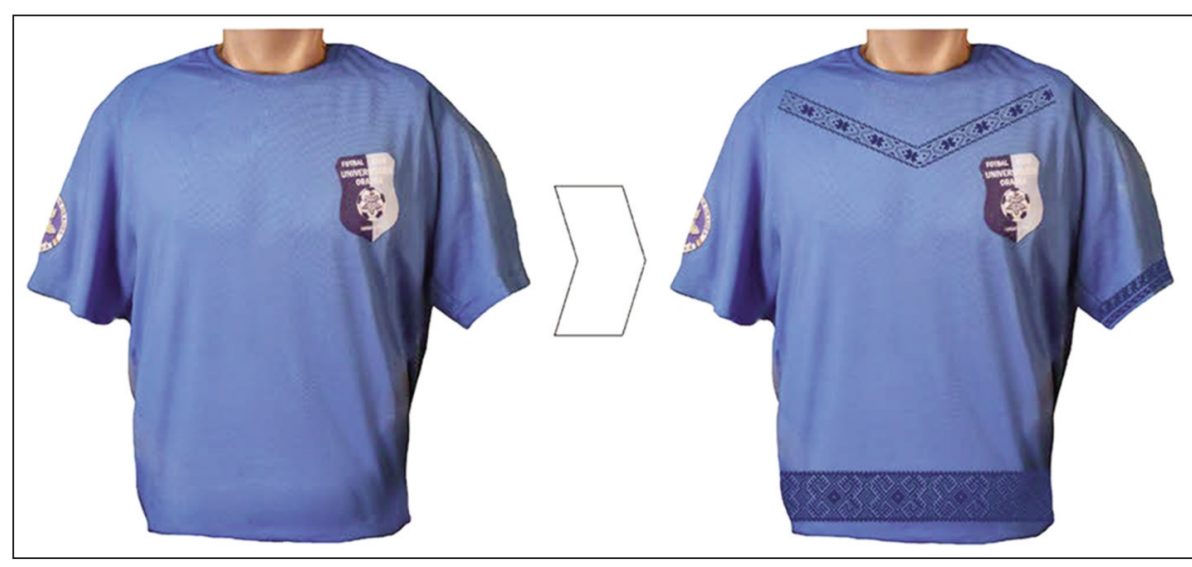

Fig. 3. Stylizing the 3D prototype of the sports shirt using the traditional Romanian motifs vectorized from the traditional peasant towels by vectorization you can get an ornament which is very difficult to achieve in the case of handmade motifs.

Considering that the old ornaments are an authentic source of inspiration for the production of modern textiles, the vectorized motifs represented the basis of the digital stylization of a polyester t-shirt dedicated to sports activities (figure 3 ).

In the MeshLab 2020.2 program, after importing the $3 \mathrm{D}$ model of the $\mathrm{t}$-shirt and the vectorized motifs, it was proceeded to the manual positioning of the last ones at the level of the garment. This operation is a great time consuming considering that for the development of a model with a high accuracy it is necessary to take into account the colour of the parts, the angles of the models and the texture of each one. Figure 3 depicts the 3D prototype obtained from the assembly of old traditional elements on a support made of new/modern material; thus, the motives used to acquire the true sense of inheritance transmitted to future generations, through renewal of the past.

\section{CONCLUSIONS}

As techniques related to digitization, 3D modelling and vectorization of textile materials are shown as efficient and integrated ways of data analysis and processing in the context of the circular economy.
Creating prototype garments based on material obtained from old or unused textiles in a fully digital format is a first step in the process of restoring these pieces. By reconstructing the digital stylization of the garments, the number of test samples necessary to finalize a final model is drastically reduced. At the same time, the techniques used offer easy access to objects and collections far away, they limit the direct contact with the pieces, at the same time being characterized by low costs of data acquisition and processing; opportunities that prove vital in the field of textile heritage research. This approach can be very useful both in terms of analysis on heritage textiles in order to preserve them, and in the fashion industry to streamline the creative process. The prototypes thus obtained, can be used in the creation of online content, adequate visualization, reconstruction of real pieces and creation of similar copies using 3D printing, preservation and promotion among the population samples that appreciate the authentic.

\section{ACKNOWLEDGEMENTS}

The current research was made possible by the equally strong scientific involvement of all the authors concerned, who wish to acknowledge the support of the Grant PN-IIIP1-1.2-PCCDI-2017-0686.

\section{REFERENCES}

[1] Jia, F., Yin, S., Chen, L., Chen, X., Circular Economy in Textile and Apparel Industry: A systematic Literature review, In: Journal of Cleaner Production, 2020, 259, 120728, https://doi.org/10.1016/j.jclepro.2020.120728

[2] Ghisellini, P., Ulgiati, S., Circular economy transition in Italy. Achievements, perspectives and constraints, In: Journal of Cleaner Production, 2019, 243, 118360, http://doi.org/10.1016/j.jclepro.2019.118360

[3] Dieterle, M., Schäfer, P., Viere, T., Life cycle gaps: interpreting LCA results with a circular economy mindset, In: Procedia CIRP, 2018, 69, 764-768, http://doi.org/10.1016/j.procir.2017.11.058 
[4] Hartley, K., van Santen, R., Kirchherr, J., Policies for transitioning towards a circular economy: Expectations from the European Union (EU), In: Resources, Conservation and Recycling, 2020, 155, 104634, https://doi.org/ 10.1016/j. resconrec.2019.104634

[5] Urbinati, A., Manfredi Latilla, V., Chiaroni, D., The role of product design in circular economy business models, Paper presented at the ISPIM Innovation Conference - Innovation, the Name of the Game, Stockholm, Sweden, 2018, 17-20

[6] Migliore, M., Oberti, I., Talamo, C., Circular Economy and Recycling of Pre-consumer Scraps in the Construction Sector. Cross-Sectoral Exchange Strategies for the Production of Eco-Innovative Building Products, In: Regeneration of the Built Environment from a Circular Economy Perspective, Springer, Cham, 2020, 217-228

[7] Jawahir, I. S., Bradley, R., Technological elements of circular economy and the principles of 6R-based closed-loop material flow in sustainable manufacturing, In: Procedia Cirp, 2016, 40, 1, 103-108, http://doi.org/ 10.1016/j.procir.2016.01.067

[8] Steinhilper, R., Weiland, F. Exploring new Horizons for remanufacturing an up-to-date Overview of Industries, products and Technologies, In: Procedia CIRP, 2015, 29, 769-773, http://doi.org/10.1016/j.procir.2015.02.041

[9] Moraga, G., Huysveld, S., Mathieux, F., Blengini, G. A., Alaerts, L., Van Acker, K., de Meester, S., Dewulf, J., Circular economy indicators: What do they measure?, In: Resources, Conservation and Recycling, 2019, 146, 452-461, http://doi.org/10.1016/j.resconrec.2019.03.045

[10] Păcurariu, R. L., Nan, L. M., Bîrgovan, L. A., David, M., Geanina, C., The implementation of the circular economy in the textile industry, In: Review of Management \& Economic Engineering, 2019, 18, 4, 558

[11] Koszewska, M., Circular Economy - Challenges for the Textile and Clothing Industry, In: Autex Research Journal, 2018, 18, 4, 337-347, http://doi.org/10.1515/aut-2018-0023

[12] Briefing EU Legislation in Progress February, 2017 (https://www.europarl.europa.eu/news/ro/headlines/priorities/ econo mia-circulara; Reimers 1994)

[13] Kębłowski, W., Lambert, D., Bassens, D., Circular economy and the city: an urban political economy agenda, In: Culture and Organization, 2020, 26, 2, 142-158, http://doi.org/10.1080/14759551.2020.1718148

[14] Melgarejo, V., Circular Economy and the Textile Industry in Paraguay, In: Población y Desarrollo, 2019, 25, 49, $143-150$

[15] Al-Makhadmah, I.S., The role of virtual museum in promoting religious tourism in Jordan, In: GeoJournal of Tourism and Geosites, 2020, 28, 1, 268-274

[16] Sharmin, F., Mohammad Tipu Sultan, M., Badulescu, D., Badulescu, A., Borma, A., Li, B., Sustainable Destination Marketing Ecosystem through Smartphone-Based Social Media: The Consumers, In: Sustainability, 2021, 13, 4, 2308, https://doi.org/10.3390/su1304230

[17] Indrie, L., Zlatev, Z., Ilieva, J., Ilies, D.C., Sturza, A., Dochia, M., Gozner, M., Herman, G.V., Implementation of image processing techniques as a tool for form analysis of Romanian folk elements, In: Industria Textila, 2020, 71, 5, 492-498, http://doi.org/10.35530/IT.071.05.1690

[18] Ilies D. C., Herman, G. V., Caciora, T., Ilies, A., Indrie, L., Wendt, J., Axinte, A., Diombera, M., Lite, C., Berdenov, Z., Albu, A., Considerations Regarding the Research for the Conservation of Heritage Textiles in Romania, In: Textile Industry and Waste, IntechOpen, 2020, http://dx.doi.org/10.5772/intechopen.91393

[19] Deac, L.-A., Gozner, M., Sambou, A., Ethnographic museums in the rural areas of Crișana Region, Romania Keepers of local heritage, tradition and lifestyle, In: GeoJournal of Tourism and Geosites, 2019, 27, 4, 1251-1260

[20] Indrie, L., Oana, D., Ilieș, M., Ilieș, D.C., Lincu, A., Ilieș, A., Baias, Ș., Herman, G.V., Onet, A., Costea, M., Marcu, F., Burtă, Ș., Oana, I., Indoor air quality of museums and conservation of textiles art works. Case study: Salacea Museum House, Romania, In: Industria Textila, 2019, 70, 1, 88-93, http://doi.org/10.35530/IT.070.01.1608

[21] Stoica, I.A., Hodor, N., Tudose, T., Coldea, G., Expected Floristic Changes in Hygro-Cryophilic and Snowbed Plant Communities Caused by Climate Change and Human Impact in The Romanian Carpathians, In: Contribuţii Botanice, 2017, LII, 163-181

[22] Ilieș, D.C., Oneț, A., Marcu, F.M., Gaceu, O.R., Timar, A., Baias, Ș., Ilieș, A., Herman, G.V., Costea, M., Țepelea, M., Josan, I., Wendt, J., Investigations on air quality in the historic wooden church in Oradea City, Romania, In: Environmental Engineering \& Management Journal, 2018, 17, 11, 2731-2739, http://doi.org/10.30638/ eemj.2018.272

[23] Kumar, R. A., Sathya, R. I., Importance of digitization process in textiles, In: International Journal of Innovative Research in Computer \& Communication Engineering, 2015, 3, 7, 7011-7015, http://doi.org/10.15680/ijircce. 2015.0307098

[24] Angheluţă, L. M., Rădvan, R., 3D digitization of an antique decorative textile artefact using photogrammetry, In: Romanian Reports in Physics, 2017, 69, 801

[25] Agosto, E., Ardissone, P., Bornaz, L. and Dago, F., 3D Documentation of Cultural Heritage: Design and Exploitation of 3D Metric Surveys, In: Applying Innovative Technologies in Heritage Science, IGI Global, 2020, 1-15

[26] Champion, E., Rahaman, H., 3D digital heritage models as sustainable scholarly resources, In: Sustainability, 2019, 11, 8, 2425, http://doi.org/10.3390/su11082425

[27] Fernández-Palacios, B. J., Morabito, D., Remondino, F., Access to complex reality-based 3D models using virtual reality solutions, In: Journal of Cultural Heritage, 2017, 23, 40-48, http://doi.org/10.1016/j.culher.2016.09.003

[28] Calvert, S., Power, J., Ryall, H., Bills, P., Reconstructing textile heritage, In: Journal of Writing in Creative Practice, $2014,7,3,415-425$

[29] Alshawabkeh, Y., El-Khalili, M., Almasri, E., Bala'awi, F. and Al-Massarweh, A., Heritage documentation using laser scanner and photogrammetry. The case study of Qasr Al-Abidit, In: Jordan Digital Applications in Archaeology and Cultural Heritage, 2020, 16, e00133

[30] Rudolf, A., Cupar, A., Stjepanovič, Z., Supporting Digitalization in Garment Engineering Through Virtual Prototyping, In: Advanced Textiles for a Better World, 2019, 10-14, http://doi.org/10.35530/TT.2019.02 
[31] Rudolf, A., Cupar, A., Stjepanovič, Z., Designing the functional garments for people with physical disabilities or kyphosis by using computer simulation techniques, In: Industria Textila, 2019, 70, 2, 182-191, http://doi.org/10.35530/lT.070.02.1592

[32] Remondino, F., Heritage Recording and 3D Modeling with Photogrammetry and 3D Scanning, In: Remote Sensing, 2011, 3, 6, 1104-1138, http://doi.org/10.3390/rs3061104

[33] Scopigno, R., Callieri, M., Cignoni, P., Corsini, M., Dellepiane, M., Ponchio, F., Ranzuglia, G., 3D Models for Cultural Heritage: Beyond Plain Visualization, In: Computer, 2011, 44, 7, 48-55, http://doi.org/10.1109/mc.2011.196

[34] Romocea, T., Oneț, A., Sabău, N.C., Oneț, C., Herman, G.V., Pantea, E., Change of the groundwater quality from industrial area Oradea, Romania, using Geographic Information Systems (GIS), In: Environmental Engineering \& Management Journal, 2018, 17, 9, 2189-2199, http://doi.org/10.30638/eemj.2018.217

[35] Ilieș, D.C., Oneț, A., Herman, G., Indrie, L., Ilieș, A., Burtă, L., Gaceu, O., Marcu, F., Baias, S., Caciora, T, Marcu, A.P., Oana, I. P., Costea, M., Ilies, M., Wendt, J., Mihincău, D., Exploring the Indoor Environment of Heritage Buildings and its Role in the Conservation of Valuable Objects, In: Environmental Engineering and Management Journal, 2019, 18, 12, 2579-2586

\section{Authors:}

\section{ADINA VICTORIA ALBU ${ }^{1}$, TUDOR CACIORA ${ }^{2}$, ZHARAS BERDENOV ${ }^{3}$, DORINA CAMELIA ILIES ${ }^{4}$, BOGDAN STURZU ${ }^{5}$, DANIELA SOPOTA ${ }^{2}$, GRIGORE VASILE HERMAN ${ }^{4}$, ALEXANDRU ILIES ${ }^{4}$, GABRIELLA KECSE ${ }^{2}$, CARMEN GEORGETA GHERGHELES ${ }^{6}$}

${ }^{1}$ Department of Textiles, Leather and Industrial Management, Faculty of Energy Engineering and Industrial Management, University of Oradea, Oradea, Romania

${ }^{2} \mathrm{PhD}$. Candidate, Doctoral School in Geography, University of Oradea, Oradea, Romania

${ }^{3}$ Department of Physical and Economic Geography, Faculty of Science, Gumilyov Eurasian National University, Nur-Sultan, Republic of Kazakhstan

${ }^{4}$ Department of Geography, Tourism and Territorial Planning, Faculty of Geography, Tourism and Sport, University of Oradea, Oradea, Romania

${ }^{5}$ Department of Physical Education, Sports and Physiotherapy, Faculty of Geography, Tourism and Sport, University of Oradea, Oradea, Romania

${ }^{6}$ Faculty of Environmental Protection, University of Oradea, Oradea, Romania

\section{Corresponding author:}

CARMEN GEORGETA GHERGHELES

e-mail: i_carmen_g@yahoo.com 